\title{
Moderating Role of Psychological Capital on Relationship between Work-Family Conflict and Job Satisfaction among Working Mothers
}

\author{
Prajnadhyma Bramadewandhana and Endang Parahyanti \\ Psychology Faculty, University of Indonesia, Depok, Indonesia
}

E-mail: prajnadhyma.brama@ui.ac.id

\begin{abstract}
Based on previous research and survey, women (especially mothers) generally have lower job satisfaction than men (especially fathers). We suspect work-family conflict to be the main cause of this phenomenon. Based on previous studies, we also propose psychological capital as a potential buffer to reduce work-family conflict's negative effect. We examined the relationship of both work-family conflict's directions (work interference with family and family interference with work) and job satisfaction, along with the moderating effect of psychological capital on 205 working mothers in vicinity of Jakarta. We distribute questionnaires containing the three instruments measuring our three variables. The results showed there was a significant negative correlation between work interference with family and job satisfaction. There also was a significant negative correlation between family interference with work and job satisfaction. For the moderating effect, results showed that psychological capital unable to moderate the relationship of both directions of work-family conflict and job satisfaction. The results implied that we should pay more attention to work-family conflict to prevent job satisfaction from decreasing. This research also has extended current researches about relationship between work-family conflict and job satisfaction by examined psychological capital's potential as a buffer.
\end{abstract}

Keywords: work-family conflict; work interference with family; family interference with work; job satisfaction; psychological capital

\section{Introduction}

Role of women in community has developed through the ages. At first, women (especially mothers) were only considered to have the role as housekeepers (Tjaja, 2000), but nowadays, the role of mothers as breadwinner started to be accepted in community (Hoffman \& Nye, 1984). This phenomenon is shown by increased amount of working women in Indonesia. According to a survey conducted by Dinas Komunikasi, Informatika, dan Statistik Pemprov DKI Jakarta (2015), in August 2015, the number of working women was increased by approximately 57 thousand people.

Besides the phenomenon of increased female workers, it was founded in previous research which stated that women's job satisfaction is lower than men's (Kanwar, Singh, \& Kodwani, 2012; Luo, 2016). A similar result also founded in a survey by Pew Research Center, that found the amount of working mother whose satisfied with their job is only $21 \%$ of the research population and for working father, it's 38\% (Parker \& Wang, 2013).

Working mother's low job satisfaction cannot be ignored because job satisfaction describes how organization treat its employee, describe how well organization's functioning, and can affect organization's function (Spector, 1997). Before we explain job satisfaction further, we will explain the Theory of Work Adjustment (TWA), which underlie the job satisfaction theory we used. TWA explain about the fit and interaction between $\mathrm{P}$ (Person) and E (Environment) (Dawis, 2000, in Dawis, 2004), in which P and E fulfill each other's need and interact with mutual give and take (Dawis, 2004). Based on this, Dawis (2004) define job satisfaction as affective response to the cognitive evaluation of $\mathrm{P}-\mathrm{E}$ correspondence (perception of how well E's reinforcers correspond to P's values and needs). 
If job satisfaction level isn't kept high, it will lead to bad outcomes such as decreased job performance (Iaffaldano \& Muchinsky; Petty, McGee, \& Cavender, in Spector, 2000), increased turnover (Crampton \& Wagner; Dickter, Roznowski, \& Harrison, in Spector, 2000), increased absenteeism (Farrell \& Stamm; Tharenou, in Spector, 2000), and decreased health and well-being (Begley \& Czajka; O’Driscoll \& Beehr; Jex \& Gudanowski; Thomas \& Ganster, in Spector, 2000).

High job satisfaction level needs to be maintained. Therefore we need to know the causes that can decrease job satisfaction. Spector (2000) presented antecedents of job satisfaction, which divided into two types, that is personal antecedents and environmental.

Antecedents. Environmental antecedents include job characteristics, role ambiguity, role conflict, work-family conflict, and pay. Personal antecedents include personality, negative affectivity, locus of control, gender, and age. Because we tried to find the causes of mother's low job satisfaction, we chose the antecedent that was more likely to be experienced by mothers, that is work-family conflict, which more likely experienced by Mothers (Tjaja, 2000; Duxbury \& Higgins, 1991).

Work-Family conflict is a form of inter-role conflict in which the role pressures from the work and family domains are mutually incompatible in some respect (Kahn et al., in Greenhaus \& Beutell, 1985). To be more precise, participation in the work (family) role is made more difficult by participation in the family (work) role (Greenhaus \& Beutell, 1985). Working mothers have two extremely important roles, that is, as a mother that foster her family and as worker to earn income. Thus these two roles together create high stress and demand (Poduval \& Poduval, 2009).

According to previous researches, Work-family conflict has two directions; work-interference with family (WIF) and family-interference with work (FIW) (Carlson \& Kacmar; Frone, Yardley, \& Markel; Hashim, Ishar, Rashid, \& Masodi, in Bagherzadeh, Taghizadeh, Mohammadi, Kazemnejad, Pourreza, \& Ebadi, 2016). WIF arises when work role negatively impacts the home/family role, and FIW occurs when problems and issues at home/family follow the person to work and hinder their work role (Lambert, Hogan \& Altheimer, 2009).
For each direction, there exist three forms of workfamily conflict, those are: time-based conflict, strain-based conflict, and behavior-based conflict (Greenhaus \& Beutell, 1985). Time-based conflict occur when time spent on activities within one role cannot be devoted to activities within another role (Greenhaus \& Beutell, 1985). Strain-based conflict exists when strain in one role affects one's performance in another role (Pleck et al., in Greenhaus \& Beutell, 1985). Behavior-based conflict happens when specific patterns of behavior in a role may be incompatible with expectations regarding behavior in another role (Greenhaus \& Beutell, 1985). In this research, we focused on two directions, due to our assumptions that these three forms have included in the two directions.

At explaining work-family conflict, we used the perspective of Conservation of Resources Theory (COR), which explained about that people will strive to retain, protect, and build resources, and minimize any threats they face (Hobfoll, 1989). Resources were explained by Hobfoll (2002) as entities that either are valued in their own right (e.g., peace) or act as a means to obtain those valued things (e.g., time, to obtain money). Hobfoll (1989) divide these resources into four types, that was object (e.g., house), condition (e.g., marital

status), personal characteristics (e.g., psychological capital), and energy (e.g., time). In this research, we focus on personal characteristic resource, as it can function as an aid to stress resistance (Hobfoll, 1989).

Relationship of work-family conflict and job satisfaction can be derived by viewing influence of work-family conflict's two directions on job satisfaction. In WIF, incompatibility between work role and family role happened due to role in work will decrease individual's time and energy that initially should be spent on family role, therefore causing individual to feel their family role is threatened (Weiner, in Grandey, Cordeiro, \& Crouter, 2005). When individual feel their important role is threatened, they appraise the source of threat negatively (Carlson \& Kacmar; Greenhaus \& Beutell; Lazarus, in Grandey et al., 2005). In this case, work role is seen as source of threat, therefore will be appraised negatively and decrease job satisfaction. On this basis, we proposed our first hypothesis:

Hypothesis 1.1.: Work Interference with Family is negatively correlated with job satisfaction. 
In FIW, according to COR theory, pressure and stress that rise due to dealing with family issues will reduce individual's time and energy on their work, which will cause attitudinal responses, such as job satisfaction (Karl, Olive, Khangelani, Brian, \& Nompumelelo; Love, Tatman, \& Chapman; Linda, Steven, Jeanne, \& Carles, in Gao, Shi, Niu, dan Wang, 2012). In addition, COR theory proposes that interrole conflict (in this case, work-family conflict) led to stress because resources from both domains (work and family) were lost in the process of juggling both roles (Grandey \& Cropanzano, 1999). Therefore, stress caused by dealing with family issues will spill over to work roles, then reducing individual's resources for work, which lead to decrease in job satisfaction (Gao et al., 2012). On this basis, we proposed our second hypothesis:

Hypothesis 1.2.: Family Interference with Work is negatively correlated with job satisfaction.

Besides to know work-family conflict and job satisfaction relationship, we should also know what variable that can reduce work-family conflict's negative influence. Gao et al. (2012) suggest that research about work-family conflict could be extended by investigating other type of resources which can act as buffer, and its known that personal characteristic resources can hinder the effect of stress (Wang, Liao, Zhan, \& Shi; Hobfoll, in Gao et al., 2012). Hobfoll (1989) explained personal characteristic is a type of resource which can help reducing stress. With having personal characteristic resource, negative effects of work-family conflict can be hindered. Personal characteristic resource that will be proposed is psychological capital.

Psychological Capital is positive psychological state of development and is characterized by (1) selfefficacy, having confidence to take on and put effort in order to succeed; (2) optimism, can make positive attribution about succeeding now ad in the future; (3) hope, preserving toward goal and able to redirect path to succeed if needed; and

(4) resiliency, able to sustain and bounce back when faced with problems (Luthans, Youssef, \& Avolio, 2007).

Previous research by Karatepe \& Karadas (2014) found that psychological capital was able to make individuals manage and protect themselves from further conflict in work and family interface. Also, research by $\mathrm{Pu}, \mathrm{Hou}, \mathrm{Ma}$, and Sang (2016) shown that psychological capital was able to moderate the positive relationship between work-family conflict and job burnout, in which psychological capital weaken the positive relationship. Inferred from these researches, psychological capital is able to reduce work-family conflict and its effect.

In addition, the effect of psychological capital is drawn from the function of each of its dimensions, which can make people be able to deal with their problem better (Avey, Luthans, Jensen, 2009; Badran \& Youssef-Morgan, 2015; Luthans, Youssef et al., 2007). Self-efficacy will affect how individuals perceive and interpret events (Avey et al., 2009). Those with low efficacy more likely to believe that efforts to solve difficult problems are futile so they are more prone to experience negative stress, while those with higher levels of efficacy are more likely to perceive problems faced as surmountable given sufficient effort (Bandura, in Avey et al., 2009). With optimism, individuals will be able to bounce back from setbacks, remain positive and confidence in the future, and have a feeling for controlling their own destiny (Luthans, Youssef, et al., 2007).

With hope, individuals are able to create realistic and challenging goals, and able to reach it with determination, high energy, and sense of control over their problems (Snyder, in Luthans, Youssef, et al., 2007). Individuals are also able to shift to alternative path when they got stuck in the initial path (Snyder; Snyder, Ilardi, Michael, \& Cheavens; Snyder, Rand, \& Sigmon, in Luthans, Youssef, et al., 2007). With resiliency, individuals will be able to bounce back from problems they face and improve themselves to solve their problem (Luthans, Youssef, et al., 2007).

Therefore, from these arguments, we assume psychological capital will be able to moderate relationship between work-family conflict and job satisfaction, especially decrease work-family conflict's negative influence. This assumption will be applied to both work-family conflict's directions, as we assume psychological capital's way to reduce work-family conflict's influence is same in both directions. Thus, we proposed another two hypotheses:

Hypothesis 2.1.: Psychological Capital is able to moderate the relationship between work interference with work and job satisfaction. 
Hypothesis 2.2.: Psychological Capital is able to moderate the relationship between family interference with work and job satisfaction.

\section{Methods}

Sample. Respondents in this research are 250 working mothers in the vicinity of Jakarta. The ages of respondents ranged from 24 to 53 years. We chose the respondents based on a few characteristics that were correlated with work-family conflict in previous research, such as have a role as a working mother (Tjaja, 2000), have youngest child at the age between 0 to 12 years (Bedeian et al., in Zhang \& Liu, 2011), and have working husband (Lewis \& Cooper, in Ochsner, 2012). These characteristics were chosen because these were characteristics of person who had high level of work-family conflict. Other characteristics we considered as control variables were length of service (Cinnamon \& Rich, 2005) and respondent's age Demerouti, Peeters, \& van der Heijden, 2012).

Research Design. By design, this research belongs to cross-sectional study, retrospective study, and non-experimental study. It is cross-sectional because we only collected our data once per respondent, retrospective study because we tried to explain a past phenomenon, and non-experimental study because we tried to saw possible causes of the studied phenomenon (Kumar, 2005).

Instrument and Measurement. For job satisfaction, was measured using Minnesota Satisfaction Questionaire-short form (MSQ-short form) that was developed by Weiss, Dawis, England, and Lofquist (1967), and adapted to Bahasa Indonesia. This instrument consisted of 20 items of six points Likert Scale $(1=$ Very Dissatisfied, 6 $=$ Very Satisfied). Before the items were presented, we wrote "In my current job, how satisfied I am with..." so the respondents may understand the items easier. Reliability coefficient (using Cronbach's alpha) for this sample is 0,90 . Validity coefficient for all items are above 0,2 , it means all items are valid (Aiken \& Groth-Marnat, 2006).

Work-family conflict was measured using workfamily conflict scales (WFCS) which was created by Carlson, Kacmar, and Williams (2000) and had been adapted to Bahasa Indonesia by Handini (2013). This instrument included 18 items measuring two directions of work-family with six points Likert scale $(1=$ Strongly Disagree, $6=$ Strongly Agree) . Reliability coefficient for this instrument is 0,84 for
WIF section and 0,78 for FIW section. For validity, all items are valid with coefficient above 0,2 (Aiken \& Groth-Marnat, 2006) except item number 6, which was deleted due to its negative validity. Thus we only used 17 in total when we analyzed the data.

The psychological capital was measured using Psychological Capital Questionnaire-24 (PCQ-24) which was developed by Luthans, Youssef, et al. (2007). This instrument contained 24 items measuring the four dimensions of psychological capital (each dimensions are represented by six items. Even having four dimensions, Luthans, Youssef, et al. (2007) suggested that psychological capital is better analyzed as a whole, not each dimensions analyzed separately, because those four had synergy with each other. Therefore we measured psychological capital by its total score. This instrument uses six-point Likert scale (1= Strongly Disagree, 6= Strongly Agree). Reliability coefficient for this instrument is 0,86. All items were valid with coefficient above 0,2 (Aiken \& Groth-Marnat, 2006) except item number 20, which have validity below 0,2 . Therefore item number 20 was deleted and only 23 items were analyzed.

Procedure. We distributed a booklet containing three questionnaires to 250 respondents by online and offline. From 250 booklet distributed, 45 of them couldn't be analyzed because the questionnaires were not filled completely. All respondents were given souvenir as compensation for their time filling the questionnaires. After the questionnaires were collected, we analyzed it using Microsoft Excel and SPSS. Relationship between work-family conflict and job satisfaction was analyzed using Pearson correlation, and moderation effect of psychological capital was analyzed using Hayes PROCESS. In Hayes PROCESS, we input job satisfaction as outcome variable (Y), psychological capital as moderating variable (M), and WIF and FIW as independent variable $(\mathrm{X})$.

\section{Results}

To test first and second hypothesis, we used Pearson correlation. For WIF results is shown below:

Table 1.

Relationship between WIF and Job Satisfaction

\begin{tabular}{ccc}
\hline Variables & $\mathbf{r}$ & Sig.(p) \\
\hline $\begin{array}{l}\text { WIF and Job } \\
\text { Satisfaction }\end{array}$ & -0.32 & $0.00^{* *}$ \\
** significant at l.o.s. 0,01 (one-tailed) &
\end{tabular}


The result showed that there was negative and significant correlation between WIF and job satisfaction ( $\mathrm{r}=-0,32, \mathrm{n}=205, p<0,05$, one-tail). This significant result means that hypothesis 1.1. was supported. Negative relationship between these two variables indicated that if WIF increase, job satisfaction would decrease. For FIW results is shown below:

Table 2.

Relationship between FIW and Job Satisfaction

\begin{tabular}{ccc}
\hline Variable & $\mathbf{r}$ & Sig.(p) \\
& & \\
\hline FIW and Job & -0.29 & $0.00 * *$ \\
Satisfaction & & \\
$* *$ significant at l.o.s. 0,01 (one-tailed) &
\end{tabular}

The result showed that there was negative and significant correlation between FIW and job satisfaction ( $\mathrm{r}=-0.29, \mathrm{n}=205, p<0.05$, one-tail). This significant result means that hypothesis 1.2 . was supported. Negative relationship between these two variables mean that if FIW increase, job satisfaction would decrease.

Below is analysis for moderation effect on relationship between WIF and job satisfaction, with job satisfaction as the outcome variable:

Table 3.

Moderation Effect of Psychological Capital in Relationship between WIF and Job Satisfaction

\begin{tabular}{ccc}
\hline Variables & Coeff. & Sig.(p) \\
\hline $\begin{array}{c}\text { Psychological } \\
\text { Capital }\end{array}$ & $0.7711(b 1)$ & 0.0000 \\
Int_1 & $-0.0027(b 3)$ & 0.7763 \\
\hline Interactions: Int_1= Psychological Capital X WIF
\end{tabular}

Based on table 3., psychological capital was positively correlated and significant with job satisfaction $(b l=0.7711, \quad \mathrm{p}<0.05)$. For the moderation effect, we got coefficient of interaction term between psychological capital and workinterference with family is $b 3=-0.0027, \mathrm{p}>0.05$. Low impact of moderating effect of psychological capital indicated by coefficient $b 3$ showed that psychological capital was not able to weaken the relationship between WIF and job satisfaction, thus hypothesis 2.1 was rejected. Below is analysis for moderation effect on relationship between FIW and job satisfaction:
Table 4.

Moderation Effect of Psychological Capital (PC) in Relationship between FIW and Job Satisfaction

\begin{tabular}{ccc}
\hline Variables & $\mathbf{r}$ & Sig.(p) \\
\hline $\begin{array}{c}\text { Psychological } \\
\text { Capital }\end{array}$ & $0.8083(b l)$ & 0.0000 \\
Int_1 & $-0.0051(b 3)$ & 0.6020 \\
\hline \multicolumn{2}{l}{ Interactions: int_1= Psychological Capital X FIW }
\end{tabular}

Based on table 4., psychological capital was positively correlated with job satisfaction $(b l=$ $0.8083 \mathrm{p}<0.05$.). This result is a bit similar when psychological capital correlation with job satisfaction was tested using WIF as the independent variable, thus it is certain that psychological capital is correlated with job satisfaction. For the moderation effect, the result showed the low impact of moderating effect of psychological capital indicated by coefficient $b 3=-$ $0.0051, \mathrm{p}>0.05$., therefore psychological capital was not able to weaken the relationship between WIF and job satisfaction. Therefore hypothesis 2.2 was rejected.

\section{Discussions and Conclusions}

Discussions. Based on our results, we got negative relationship between both directions of work-family conflict and job satisfaction. We also got that psychological capital was unable to moderate the relationship between the two directions of workfamily conflict and job satisfaction.

Our results showed that WIF and FIW were negatively correlated with job satisfaction. This result was consistent with the previous research such as Gao et al. (2012) and Allen, Herst, Burck, and Sutton (2000). This relationship can be explained by seeing two directions of work-family conflict. From WIF, incompatibility between work and family role happened because high demand in work role will deplete individual's time and energy which initially used for family role. Therefore it will threaten the family role (Weiner, in Grandey et al., 2005). If a role is felt like a threat, individual will appraise the threat negatively (Carlson \& Kacmar; Greenhaus \& Beutell; Lazarus, in Grandey et al., 2005). Therefore, work role will be seen negatively, and it means individual is not satisfied with his/her work.

From FIW, work-family conflict will cause stress in both domains (work and family) because resources in both domains are lost in process of juggling both 
roles (Grandey \& Cropanzano, 1999). Therefore, stress caused by family roles will spill over to work roles, then depleting individual's resources for work, which lead to decrease in job satisfaction (Gao et al., 2012).

For the moderation effect, the results are different from our hypotheses, because the psychological capital was unable to have a role as a buffer. We assume that these results happened because most of our respondents had low WIF and FIW. According to Lazarus and Folkman, in Hobfoll (2002), a resource will be used when individual need it. Therefore positive resource effect will be limited if individual is not facing a stressful event and need a resource. In our research, most of our respondents had low WIF (74,14\% of sample) and low FIW (93,65\% of sample). Having not currently faced stressful event, we assume our respondents did not really need resources like psychological capital to support them up. Therefore the effect of psychological capital was not significant because the respondents didn't feel they had psychological capital or didn't use it in the time we collect the data.

There are several limitations in our study. First, instrument we use has a problem with its item, which 2 items were not valid, even after we tried to fix it. Our suggestion is to adapt the instruments better, because instruments we use was not valid maybe due to the items didn't match the context in our country. Second, related to our result in moderation effect, we failed to get significant results maybe because our respondents didn't have high levels of work-family conflict. We suggest that further research should ensure the respondents have high levels of work-family conflict.

Third, our limitation is we only see two directions of work-family conflict, while in it there are three forms, that is, time-based, strain-based, and behavior-based. We suggest further research would include these three forms along with the two directions so we could more fully grasp the influence of work-family conflict.

For future research, we suggest trying examining another type of positive resource to moderate the relationship between work-family conflict and job satisfaction. According to Wang, in Gao et al. (2012), another types of resource such as physical resource (e.g. muscle strength), financial resources (e.g. incomes), social resources (e.g. social support), cognitive resources (e.g. emotional intelligence), emotional resources (e.g. mood), and motivational resources (e.g. goal orientation).

Our research has several implications. First, by getting the results of negative. Relationship between work-family conflict and job satisfaction, work organizations should pay more attention to work-family conflict to prevent job satisfaction from decreasing. This can be done by having flexible work time or child care, which can make individual's family role undisturbed. Second, we extend current researches about work-family conflict by examining new type of buffer such as psychological capital.

Conclusion. In conclusion, our research results showed that there were negative and significant relationship between both directions of work-family conflict (WIF and FIW). Other results showed that psychological capital was unable to moderate the relationship between both directions of work-family conflict and job satisfaction.

\section{References}

Aiken, L. R. \& Groth-Marnat, G. (2006). Psychological Testing and Assessment. Boston: Alyn \& Bacon.

Akter, A., Wali, S. B., Kamal, M. R., Mukul, A. Z. A., \& Mahmuda, M. (2017). Factors affecting job satisfaction of working mothers of readymade garments sector in Bangladesh. Issues in Bussiness Management and Economics, 5(2), 2536. Doi: 10.15739/IBME.17.004

Allen, T. D., Herst, D. E., Bruck, C. S., \& Sutton, M. (2000). Consequences associated with work-tofamily conflict: a review and agenda for future research. Journal of occupational health psychology, 5(2), 278-308. DOI: 10.1037//1076899B.5.2.278

Avey, J. B., Luthans, F., \& Jensen, S. M. (2009). Psychological capital: A positive resource for combating employee stress and turnover. Human resource management, 48(5), 677-693. DOI: 10.1002/hrm.20294

Badran, M. A.,\& Youssef-Morgan, C. M. (2015). Psychological capital and Job Satisfaction in Egypt. Journal of Managerial Psychology, 30(3),346 - 370. DOI: 10.1108/JMP-06-20130176

Bagherzadeh, R., Taghizadeh, Z., Mohammadi, E., Kazemnejad, A., Pourreza, A., \& Ebadi, A. (2016). Relationship of work-family conflict with burnout and marital satisfaction: cross-domain or source attribution relations?. Health promotion 
perspectives, 6(1), 31. DOI:

10.15171/hpp.2016.05.

Cinamon, R. G., \& Rich, Y Carlson, D. S., Kacmar, K. M., \& Williams, L. J. (2000). Construction and initial validation of a multidimensional measure of work-family conflict. Journal of Vocational behavior, 56(2), 249-276.

DOI:10.1006/jvbe.1999.1713

Carlson, D. S., Kacmar, K. M., \& Williams, L. J. (2000). Construction and initial validation of a multidimensional measure of work-family conflict. Journal of Vocational behavior, 56(2), 249- DOI:10.1006/jvbe.1999.1713

Dawis, R. V. (2004). The Minnesota Theory of Work Adjustment. In Brown, S. D. \& Lent, R. W. (Eds.), Career Development and Counseling: Putting Theory and Research to Work (3-23). Hoboken, New Jersey: John Wiley \& Sons, Inc.

Demerouti, E., Peeters, M. C., \& van der Heijden, B. I. (2012). Work-family interface from a life and career stage perspective: The role of demands and resources. International Journal of Psychology, 47(4), 241-258. DOI: 10.1080/00207594.2012.699055

Dinas Komunikasi, Informatika, dan Statistik Pemprov DKI Jakarta (2015). Keadaan Ketenagakerjaan DKI Jakarta. Retrieved from http://www.jakarta.go.id/v2/news/2015/11/keadaaketenagakerjaan-di-dki-jakarta-agustus2015\#.WJhw2VN97IX

Duxbury, L. E., \& Higgins, C. A. (1991). Gender differences in work-family conflict. Journal of applied psychology, 76(1), 60. Retrieved from http://psycnet.apa.org/index.cfm?fa=buy.optionTo B uy\&id=1991-19993-001

Gao, Y., Shi, J., Niu, Q., \& Wang, L. (2012). WorkFamily Conflict and Job Satisfaction: Emotional Intelligence as a Moderator. Stress and Health, 29(3). DOI: 10.1002/smi.2451.

Grandey, A., Cordeiro, B., \& Crouter, A. (2005). A longitudinal and multi-source test of the workfamily conflict and Job Satisfaction relationship. Journal of occupational and Organizational Psychology, 78(3), 305-323. DOI: $10.1348 / 096317905 X 26769$

Grandey, A. A., \& Cropanzano, R. (1999). The conservation of resource model applied to workfamily conflict and strain. Journal of Vocational Behavior, 54, 350-370.

Greenhaus, H. J., \& Beutell, N. J. (1985). Sources of Conflict between Work and Family Roles. The Academy of Management Review, 10(1), 76-88. Retrieved from http://www.jstor.org/stable/pdf/258214.pdf?refreq id=excelsior:fec426a0686fd6dcae6bf0170fd1a358

Handini, R. E. (2013). Hubungan antara work-family conflict dan keterikatanbekerja pada ibu bekerja (Skripsi). Retrieved from Database Perpustakaan Universitas Indonesia (S45605).

Hoffman, L. N. W., \& Nye, F. I. (1974). Working Mothers. San Fransisco: Jossey-Bass Publisher

Hobfoll, S. E. (1989). Conservation of resources: A new attempt at conceptualizing stress. American psychologist, 44(3), 513. Retrieved from http://www.personal.kent.edu/ shobfoll/Files/pdfs /A P1989CORnewattempt.pdf

Hobfoll, S. E. (2002). Social and psychological resources and adaptation. Review of general psychology, 6(4), DOI: 10.1037//1089-2680.6.4.307

Kanwar, Y. P. S., Singh, A. K., \& Kodwani, A. D. (2012). A study of job satisfaction, organizational commitment and turnover intent among the IT and ITES sector employees. Vision, 16(1), 27-35. DOI: $10.1177 / 097226291201600103$

Karatepe, O. M., \& Karadas, G. (2014). The effect of psychological capital on conflicts in the workfamily interface, turnover and absence intentions. International Journal of Hospitality Management, 43, 132-143. DOI: 10.1016/j.ijhm.2014.09.005

Lambert, E., Hogan, N. L., \& Altheimer, I. (2009). The association Between Work-Family Conflict and Job Burnout Among Correctional Staff: A Preliminary Study. Am J Crim Just, 35(1), 37-55. DOI:10.1007/s12103-009-9067-1

Luo, Y. (2016). Gender and job satisfaction in urban China: The role of individual, family, and job characteristics. Social Indicators Research, 125(1), 289-309. DOI: 10.1007/s11205-014-0837$\mathrm{x}$

Luthans, F., Youssef, C. M., \& Avolio, B. J. (2007). Psychological Capital: Developing The Human Competitive Edge. New York: Oxford University Press.

Ochsner, T. J. (2012). The Impact of Dual-Career Marriage on Role Conflict and Marital Satisfaction. Communication Studies Undergraduate Publications, Presentations and Projects. Retrieved from http://pilotscholars.up.edu/cgi/viewcontent.cgi?art icle $=1073 \&$ context $=$ cst_studpubs

Poduval, J. \& Poduval, M. (2009). Working Mothers: How Much Working, How Much Mothers, And Where Is The Womanhood? Mens Sana Monographs, 7(1), 63-79. DOI: 10.4103/09731229.41799 
Spector, P. E. (1997). Job Satisfaction: Application,

Assessment, Causes, and Consequences. London:

Sage Publication, Inc.

Spector, P. E. (2000). Industrial \& Organizational Psychology: Research and Practice $\left(2^{\text {nd }} E d\right.$.). New York: John Wiley \& Sons, Inc.

Tjaja, R. P. (2000). Wanita Bekerja dan Implikasi Sosial. Retrieved from http://www.bappenas.go.id/files/6513/5228/3053/r atna_20091015151137_2386_0.pdf

Parker, K. \& Wang, W. (2013). Modern Parenthood: Roles of Moms and Dads Converge as They Balance Work and Family. Retrieved from http://www.pewsocialtrends.org/files/2013/03/FIN A L_modern_parenthood_03-2013.pdf

Pu, J., Hou, H., Ma, R., \& Sang, J. (2016). The effect of psychological capital between work-family conflict and job burnout in Chinese university teachers: Testing for mediation and moderation. Journal of Health Psychology. Advance daring publication. DOI: 10.1177/1359105316636950

Weiss, D. J., Dawis, R. V., England, G. W., \& Lofquist, L. H. (1967). Manual for the Minnesota Satisfaction Questionnaire. Minnesota: Minneapolis Industrial Center, University of Minnesota

Zhang, J., \& Liu, Y. (2011). Antecedents of work-family conflict: Review and prospect. International journal of business and management, 6(1), 89. DOI $10.1108 / 0268394121125952$ 